Article

\title{
Cultivating an Academy We Can Live With: The Humanities and Education for Sustainability ${ }^{1}$
}

\section{Lucas Johnston}

Department for the Study of Religions, Wake Forest University, 118 Wingate Hall, PO Box 7212 Reynolda Station, Winston-Salem, NC 27109, USA; johnstlf@wfu.edu

Academic Editor: Evan Berry

Received: 16 March 2016; Accepted: 7 September 2016; Published: 28 September 2016

\begin{abstract}
Many facets of the university system in North America are fundamentally unsustainable, developing and perpetuating knowledge practices that not only do not sustain the biospheric conditions in which our species evolved, but actually defray them. This analysis proceeds in three ways: (a) highlights the historical entanglement of religion and sustainability discourse and the now global concern over climate disruption; (b) it interrogates assumptions regarding whether, when, and to what extent scholars of religions should advance politically significant arguments; (c) explores problem-based learning and integrative curricular development, which may be fostered by focusing on complex wicked problems such as climate disruption.
\end{abstract}

Keywords: sustainability; climate change; religion and sustainability; higher education; education for sustainability; problem-based learning

\section{Introduction}

Although there are a variety of ways that one can interpret the concept of sustainability, by almost any definition much of the knowledge the contemporary academy produces contributes to an unsustainable civilization. As the Vice Provost of St. Mary's College Richard Carp put it, "the network of institutions that make up 'the academy', which includes not only colleges and universities, but also (at least) professional and disciplinary organizations, its sources of funding, and its methods for distributing economic and status rewards, predominantly defray rather than support resilience" ([1], p. 224). Some educators have long been aware of this fact, but because that ultimately unsustainable academic network of interests and individuals has its own inertia, it has been slow to change. The environmental educator David Orr wrote in 1991 that "sustainability is about the terms and conditions of human survival, and yet we still educate at all levels as if no ... crisis existed. The content of our curriculum and the process of education ... have not changed, the crisis cannot be solved by the same kind of education that helped create the problems" ([2], p. 83; quoted in ([3], p. 79). Unfortunately many of these shortcomings remain in the academy in general, particularly within the humanities disciplines, and I want to link climate change and education for sustainability together by wrestling with some of the obstacles which prevent change-some of the things which contribute to the inertia of the status quo.

I do so first by highlighting that contested terms like sustainability and climate disruption are themselves deeply entwined with religious and spiritual narratives, and have been part of the political economy of the sacred since they became widely deployed in the public sphere. ${ }^{2}$ The religion scholar

1 My thanks to Richard Carp, Todd LeVasseur, Bernie Zaleha, and several anonymous reviewers who provided helpful feedback on early drafts.

2 Chidester [4] uses the phrase "political economy of the sacred" to refer to the now global trafficking in popular symbols, metaphors and tropes which have their origins in or take their power from their exploitation of the religious or spiritual 
David Chidester does not specifically refer to the term sustainability in his meditations on popular religiosity in America [4], but sustainability discourses certainly fit his definition of forms of religious cultural production which are contested and disseminated through economic and political means, helping to negotiate what it means to be human.

Second, I interrogate a question raised by the scholar of religions Ivan Strenski in his criticism of the "climate change" theme for the 2014 meeting of the American Academy of Religion: "can religion professors save the planet?" [5] Both Strenski and I would answer "no", but for very different reasons. Strenski and others often worry that organizing academic work toward real-world problems instrumentalizes the humanities, potentially evacuating it of the really important sort of research that should be the hallmark of the humanities. In contrast, I think the very notion that humanities scholars ought to aim for that sort of "pure research" is one of the outmoded types of thinking that drives unsustainability by training students who are unable to solve complexly related problems at multiple scales.

Third, then, I note that one of the hallmarks of education for sustainability has been problem-based education. Far from merely instrumentalizing these disciplines, it makes them more relevant than they have been in some time.

Fourth, I suggest that one of the ways in which scholars, particularly scholars of religions might engage in problem-based learning without becoming "activists" is to treat the normativities and ontologies that inhere to social contestations over discourses of sustainability and climate change, and the political policies implicated in them, as data.

Fifth, I suggest that one form of problem-based learning, engaged learning, where students interact with and impact the communities in which they live, work, and play, can be both a worthwhile learning experience for students, and a window through which we can re-envision the shape of the Academy in general. I will conclude with some specific examples of problem-based and engaged teaching and learning from my home institution.

Re-shaping pedagogical approaches, encouraging problem-based learning, and acknowledging that terms like sustainability and climate disruption are currencies in the global political economy of the sacred are good starting points for owning the disciplinary past of religious studies and related areas of study, and for providing some positive ways forward. If we cannot re-vision the work that takes place in the academy, we cannot solve the global crises under discussion here. And we cannot re-vision that academic work without exposing the often patriarchal and erroneous assumptions which underlie the exercise of academic power in the twenty-first century. First, however, it is important to get clearer about the terms under analysis here.

\section{Climate Disruption and Sustainability Have Religious Dimensions Which Run Deep}

Climate disruption is often used as a shorthand to refer to an interlocking set of biophysical and social problems, but generally it refers to the destabilization of the planet's climate system caused by anthropogenic disturbance of the carbon cycle. The physicist John Tyndall first noted that carbon dioxide warmed the atmosphere in the 1850s. The science related to climate disruption, then, is old, but perhaps only more recently connected with religious ideation as climate disruption has quickened. In the late twentieth and early twenty-first centuries climate disruption took on important apocalyptic dimensions, in the sense that it was portrayed as bringing about a radical reduction in human populations, if not a dramatic reduction of biodiversity generally. ${ }^{3}$ For instance, the film

baggage they carry, and which do religious work (whether they are authentically religious themselves) by binding communities of people together, focusing desire, and channeling exchange relations in particular directions.

3 One reviewer suggested that I tease out theological ideas related to the term apocalypse, noting that in some theological contexts (particularly in Jewish and Christian texts produced around the turn of the Common Era) the term often referred to a sort of revelation, or unveiling. While this is certainly one use of the term, unpacking this more theological usage would not further any argument I make here. The most common understanding (and indeed the first one in most dictionaries) refers to extreme disasters which bring destruction and loss. 
The Day After Tomorrow (2004) depicted the world passing a climatic tipping-point, entering a new ice age nearly overnight. Populations across the world were decimated, and survivors flocked south, toward warmer climes. Although not overtly religious, such apocalyptic films fueled a religious brand of apocalypticism in the United States grounded in the quasi-religious belief that "peak-oil" and climate destabilization would precipitate the end of the world as we know it. In one important study, Christian apocalyptic narratives clearly conditioned concern about and behavior change related to climate disruption [6].

Defining sustainability is somewhat trickier. The term sustainability is rather like Joseph Campbell's famous "hero with a thousand faces", a slippery term that that means many things to many different people. Some imagine that the best measure for sustainability is biodiversity, while others focus on social factors and metrics (equity and justice, for example), while still others are more centrally concerned with "greening" industrial technologies and promoting technical solutions. In all cases, though, they are related to the survival of the human species within certain biophysical limits. The scholar of religions J.Z. Smith influentially argued that religion is a second-order, generic category ([7], p. 269), that there is no data for religion: "Religion is solely ....created for the scholar's analytic purposes by his imaginative acts of comparison and generalization" ([8], p. xi). Elsewhere I have argued that the same is true of sustainability [9]: it should not be imagined in an essentialist way, as a fixed goal, or endpoint, but as a function of the imaginative acts, interests, and values of the individual or group deploying the term. When individuals or groups utilize the term sustainability, they give a glimpse into their core values, those things (whether cultural practices, economic development, social equity, and so on) that they wish to see persist into the foreseeable future. In this sense sustainability is analogically related to religion, but there is also a strong genealogical relationship between the two terms.

The first uses of the term sustainability, at least as early as the mid-1800s, referred to wise human use and preservation of natural resources ([10], p. 146; [11], p. 347). It was typically related to some supposedly universal set of "goods", for instance its usefulness in preventing social chaos, or promoting patriotism, or in some cases encouraging counter-hegemonic values. The first resource management regimes in the US drew directly on these European usages of the term, but the religious dimensions of such universal goods became much more obvious. The spiritual sympathies of nature writers such as William Bartram, Thomas Morton, and the Transcendentalist authors and those they influenced, including Ralph Waldo Emerson, Henry David Thoreau, John Muir, and many others are well known. The first official federally mandated resource manager, however, was Gifford Pinchot, who was significantly influenced by the Social Gospel movement, a widespread and influential stream of Christianity which deemphasized the transcendent dimensions of the religion and sought to apply its ethical principles to the alleviation of the social ills that resulted from the so-called industrial revolution [12]. Pinchot believed the application of Christian ethical norms to the management of the commonwealth was the solution to maximizing individual utility and national well-being ([9], pp. 46-49; [13], pp. 95-96, 115). He is but one exemplar, but broader international political experiments with "development" and later the term "sustainable development" were ultimately grounded in Western religious values and norms $[9,14,15]$. The religious dimensions of these movements have played important roles in both the 20th and 21st century outgrowths of the concern for nature first spurred by the ethic of scarcity which emerged first in Europe and then the US in the 19th century. In the post-World War II period a host of new international organizations were created. The Bretton Woods institutions (the World Bank, the International Monetary Fund, and the General Agreement on Tariffs and Trade) represented the financial and economic powerhouses that would prevent the sort of poverty that many imagined had driven the world into a second global war. The United Nations (UN) and its affiliated bodies represented the liberal-democratic response to an increasingly global political culture, responsible for development, and by the 1970s, sustainable development. The UN and its affiliated bodies have paid particular attention to the religious dimensions of development. To a lesser extent, those who defended economic growth and their attendant institutions have also utilized 
spiritualized ideation and metaphor to further their aims ([9], pp. 50-71). Although a narrower notion than "sustainability", sustainable development was nonetheless grounded in Western, often Christian values related to individual economic freedom, and access to wealth generation ([9]; [14], p. 70).

Narrower still is the phrase "education for sustainability" (EfS), which began as an effort among Western European and North American institutions of higher learning to create synergistic relationships between life sciences, social sciences, humanities disciplines, and professional schools ([16], p. 1): "The most pressing problems across the globe-famines, armed conflicts, demographic transitions-are the result of dynamic biophysical, social, and psychological processes. Solving such wicked problems requires an educational system that trains students to be adaptive learners who can anticipate disruptions and envision their solutions and attendant opportunities at multiple scales-from the local to the geopolitical. Most classroom experiences do not reflect this general need" ([16], pp. 1-2). Organizing principles, such as problem-based learning, were developed to facilitate this cross-disciplinary work and illustrate the interdependence of usually disparate fields. These ideas are discussed in more detail below. My concern here is primarily with EfS, although even this narrower exercise of the notion of sustainability is beholden to the religious ideation inherent in the foundations of sustainability, and to interrogating and overcoming the received Western mode of education. But some of my suggestions toward the end indicate ways in which even this relatively ethnocentric model can be usefully decolonized.

Both sustainability and climate disruption, then, carry religious baggage, and recognizing this can help to clarify cultural responses to these terms, and also help to illustrate how humanities scholars in general can contribute to public debates about them. As the religion scholar David Chidester put it something —a social movement for instance-is doing religious work when it facilitates particular economic exchange relations, acts as a sort of social glue by promoting sets of shared languages and values, and focuses collective desire ([4], p. 5). This is certainly true of sustainability and climate change discourse, whether they are deployed to support existing hegemonic powers or to subvert them. But the religious dimensions of sustainability and climate change are not merely superficial. Sustainability movements are religious from roots to shoots, and climate change activism and public portrayal has long been linked to apocalyptic ideation [6].

Climate disruption and sustainability have elective affinities with the explosion of monitory agencies in the post-World War II period and the new technologies and media of the late 20th and early 21st centuries [17]. International political coordination proceeds along at least three fronts: the social-democratic bodies related to and derivative of the UN; the manipulation and channeling of markets through the Bretton Woods Institutions; and civil society organizations, which come in a panoply of forms and work at multiple scales, and which may subvert hegemonies, or promote them. Sustainability and climate change discourses and advocacy are increasingly central concerns of groups in all of these categories, and whether at the local or international scale these narratives, metaphors and tropes have significant religious dimensions, even in supposedly secular organizations [9].

It will be illustrative to look more closely at how these religious dimensions of climate disruption and sustainability, and specifically education for sustainability, play out in the always-political context of education.

\section{Can Religion Professors Save the Planet?}

In 2014 Laurie Zoloth, then President of the American Academy of Religion (AAR), declared that the yearly conference theme, a choice that is the prerogative of the sitting President, would focus on climate change. Scholarly interest in the nexus of religion and environmental issues goes much deeper, however, with an AAR Sustainability Task Force active from 2007-2012 [18], and a Religion and Ecology Group which dates back to 1993 [19]. Moreover, scholars in other disciplines have long attended to the nexus of various religious traditions and their biophysical contexts (just to name a few [20-29]). Despite a rich tradition of scholarly exploration of religions, cultures, and their perceptions of and behaviors related to nature, Zoloth's theme prompted some derisive reactions. 
For instance, in a piece in Religion Dispatches titled "Can Religion Professors Save the Planet?" scholar of religions Ivan Strenski proposed that such problem-based scholarship might compromise the "open-ended questioning, unbridled curiosity and pursuit of understanding" that is characteristic of humanities-oriented research [5,30]. Strenski is not alone in his critique. But such a critique is the classic example of the academic default to Western, patriarchal values, assuming that the value of pursuing knowledge for its own sake is self-evident. In fact, such an idea is reasonably new, and worth interrogating. ${ }^{4}$ At my home institution I was asked to respond to a talk by a visiting critical theorist on climate change. I suggested that there were responsible and productive ways in which education could be more problem-focused. She fretted that such an approach could "instrumentalize" the humanities, making them little more than useful tools. With Strenski, she worried this would truncate the power of creativity that characterized humanistic inspection. As Strenski put it, the AAR's focus on climate change amounted to hitching itself "to the latest star in the universe of social causes", evacuating it of any research or teaching that "have an integrity of their own". But climate change is not simply a faddish "social cause", it a robustly defended and described mass of scientific data. There is a scientific consensus [31] even if significant portions of the general populace in the US still do not assent to the notion that it is human-caused. ${ }^{5}$ This is all the more reason that scholars of any ilk, who should be savvy enough to do their homework, should not refer to matters of such profound scientific consensus as faddish social causes.

Moreover, religious studies has long embraced problem-oriented scholarship, from work on pluralism, to postcolonial studies, to queer theory, to critiques of racism and ethnocentrism. To defend the work of the academy as the disinterested and objective pursuit of knowledge about the world is to recapitulate the worst crimes of the academy. That religious studies developed constituencies which deploy the tools developed in their own peculiar training and areas of expertise to some of the most pressing problems that all carbon-based life faces seems unsurprising. What is surprising is that some scholars continue to advocate for the view that humanities scholars should engage in open-ended questioning which masquerades as value-neutral, apolitical, but which in reality reifies obvious failures in the academy. Why celebrate the "freedom" to engage in open-ended inquiry if the understanding it aims at has little or no relevance to the lives of individuals or groups? The traditional disciplinary boundaries that have divided the academy are withering, and preserving their rotting remains does little to hide, as the author and provocateur Edward Abbey once noted, that formal education can be broadening, but more often merely flattens our purview.

\section{Is "Instrumentalizing" the Humanities All Bad?}

What does it mean to instrumentalize the humanities? It seems that it would be a negative development if engineered by, say, national or state governments. For example, the humanities could be used to generate propaganda, or research favorable to particularly powerful social actors. But at least in my department, and in the academic habitats of many with whom I have spoken, humanities and even social scientific scholars consistently struggle with staying "relevant" as their departments lose majors and minors to the increasing numbers of students who flock to business schools, engineering programs, and finance or computer science departments (even at liberal arts universities, like my own). Perhaps part of the solution is to engage in scholarship that is relevant, and to more intentionally explore the methods by which we gather research data, and how we transmit it to students. I do not view Strenski's argument as evidence that we ought to leave the debates over climate disruption and

4 My thanks to Richard Carp for pointing out just how recent such assumptions are.

5 The Public Religion Research Institute (PRRI) noted that 50\% of US citizens surveyed characterize themselves as somewhat $(29 \%)$ or very unconcerned $(21 \%)$ about climate change. Interestingly, however, $74 \%$ of respondents reported that people in developing countries will suffer moderate $(20 \%)$ or great $(54 \%)$ harm. Yet climate disruption still ranks as the lowest priority among environmental issues to voters, with only $5 \%$ noting that it is the most important issue facing the US (jobs (22\%), the gap between rich and poor $(18 \%)$, health care $(17 \%)$, budget deficit $(13 \%)$, immigration reform (10\%), and cost of education $(9 \%)$ are all much greater concerns among US citizens [32]. 
sustainability out of humanities courses, but rather as an invitation to draw them into the conversation. Can the humanities save the ice caps, as Strenski put it? No, particularly since several studies indicate that the rate of warming essentially locks us in to climate patterns that will ensure the dissolution of both ice caps, the northern one within this century, and the southern one within a few [33]. What, then, can humanities scholars offer to the broaden debate, and to transform the academy?

Stephen Prothero claimed in a popular book that religion was one of the key identity markers of the twenty-first century [34]. I would agree, but terms like "climate disruption" and "sustainability" are also key identity markers, as global leaders (from Pope Francis to Prince Philip, and from Presidents Barack Obama to Evo Morales) link their own religious and national interests and religious convictions to them. One way humanities and human science scholars can contribute to the conversation is by first acknowledging that public deployments of these terms provide a window into the values, practices, and beliefs of other humans. In other words, public invocations of particular understandings of "sustainability", and their relation with religion, are inherently political. One approach, then, is to imagine that the task of the scholar of religions is not to advocate for a particular political position, or somehow rise above the public debate by deploying critical theory to deconstruct the scientific consensus, but rather to treat this consensus, and the effort of some senior scholars to retreat from these cultural debates, as data.

Strenski notes that most of the empirical research related to such questions occurs within the confines of the Society for the Scientific Study of Religion (SSSR), while the AAR is a home for non-empirical theologians and humanists. This was certainly largely true three decades ago, and indeed on its public face the trend continues. For instance, taking the President's prerogative to set the theme for the annual conference, Serene Jones declared 2016's focus to be the theologically inflected theme "revolutionary love". In her call, Jones suggests this sort of love occurs in a "state of grace" [35]. Perhaps this theological framing is merely a reminder of the theological roots of the AAR and the Society of Biblical Literature, which meet concurrently each year. Even today perhaps the bulk of papers and workshops bend toward the theological and confessional rather than the analytical or critical. Nonetheless, there have been strong genealogical critiques of such ethnocentric and theological understandings of the category religion [36-39], and a turn toward what Robert Orsi ([40], p. 8) referred to as a "radically or phenomenologically empiricist" approach in his call for the study of "lived religion". The emergent contributions from a more empirical or analytical bent have rightly been critical of this persistent theological inflection of the largest membership body in our field. As Naomi Goldenberg put it, "Aren't there already enough ecclesial and ecumenical venues that justify themselves through an ideology of love? Shouldn't the AAR be promoting something else-say, for example, the critical analysis of institutional power and pretense?" [41]. I concur, and climate change and sustainability-oriented social movements seem like prototypical cases in which various forms of capital (financial, political, social, and ecological) are exchanged in power-laden relationships, and which are ripe for analysis and commentary. But deeper problems remain, namely that these modes of inquiry are so often imagined as separate.

We might endeavor to explore the ways in which climate disruption is linked with the exercise of power, the shaping of information technologies and access, as well as tied up with important questions about what it means to be a human in a world populated by other-than-human persons. For example, what does it mean to inhabit a world in which broader ecological, atmospheric, and bio-geochemical cycles also have some agency [42], at least in the sense that they can impact the size, shape, and character of social groups and their behaviors? Asking what relevance our discipline has to the most important questions our species is faced with-namely how we can persist, and even thrive, and more importantly, what are the values that particular individuals and groups envision as measures of success or "thriving" - seems to me to be legitimate exercise of the analytical tools at our disposal. There is a difference between using critical analytical and even empirical methods to answer such questions - what I am advocating — and pushing all scholars to be sustainability activists who advance a prescriptive response to issues such as climate change. Imagining an intellectual terrain in which 
there are academics and there are activists and nothing in between is one of the tired, old dichotomies that should be put to sleep.

\section{Ontologies and Normativities Are Data}

In an introductory text for students of religion and ecology, Bauman, Bohannon, and O'Brien note that religious and scholarly responses to environmental problems can be grouped as efforts at recovery, reformation, or replacement [43]. The ecologist and evangelical Calvin DeWitt would be an example of one who advocates recovery, exploring the roots of his own tradition to reinterpret it in light of contemporary issues. The ecofeminist Rosemary Radford Ruether, who has suggested that the patriarchal and oppressive development of her Christian tradition have resulted in a parallel exploitation and oppression of earth systems, was one who forcefully tried to reform her tradition. The religion scholar Bron Taylor is offered as one whose analyses suggest that in the very long term institutionalized global religions will become less influential as they morph into more relevant forms, perhaps disappearing altogether in some cases, as new forms of global green spirituality emerge [44]. Such scholarship can be engaged in different ways, but in some cases may be dismissed by critics as inappropriately activist. For instance, DeWitt is a conservation biologist, which means that he stands within an academic discipline that is, from its inception, committed to particular values, namely the preservation and utility of biological diversity. He is also engaged with communities of evangelical Christians, and is himself an evangelist for Christian "creation care". Indeed, several leaders among the evangelical communities in which I conducted field work cited DeWitt as one of those who had convinced them that climate change was a religiously relevant issue (interviews conducted 2008). ${ }^{6}$ Is he, then, an activist and not a scholar? Ruether exercised influence within Catholic theology, feminist studies of religion, and a now widespread ecofeminist movement. Is she, too, an activist? Taylor, who openly discusses his activist roots, was the founding President of the Society for the Study of Religion, Nature, and Culture, an organization that explicitly states in its by-laws that it is not an activist or advocacy organization [45]. Yet Taylor's scholarly work on "dark green religion" is inspirational for many practitioners and purveyors of green religions. So where does one draw the line between "activist work" and "scholarly work"? If entwined, are they both compromised? One could answer that they are all activists, and therefore their scholarly work is suspect, since they are only half-scholars (and half-activists). These chimeras of the contemporary academy should not all be lumped together, however, for their methods and message are distinct, allowing some analysis regarding their efficacy but also their supposed "place" in the academy.

Among those who study the nexus of religion, nature, and culture, there are those who engage in (a) constructive or normative explorations; (b) social scientific and cultural investigations; and (c) natural scientific studies [45]. The sort of research that worries some scholars falls into the first category. In short, the worry is that the 2014 AAR conference made the study of religion about combating climate change. Certainly there are scholars who have imagined the study of religion and environment as an opportunity to advocate for particular interpretations of the so-called world religions [46-52], and others attempt to forge an entirely new type of green religion that is amenable to a number of different religious traditions. The former group represents a type of revitalization movement (parallel to the recovery or reform platforms listed above), the latter is itself a new religious movement which blends latent or under-scrutinized resources in the world's religions with scientific understanding of earth systems [53]. These are different modes of study with different aims, but both could be characterized as advocating for specific, and in some cases politicized changes within the academy and society in general. But all of these modes of scholarship and engagement can also be

6 In 2008-2009 I put together a case study of evangelical creation care movements, participating with members of a megachurch in central Florida, and interviewing several prominent evangelical advocates, as well as a number of congregants. This work was published in Religion and Sustainabiltiy [9]. 
the primary data for empirically-minded scholars of religions who analyze the ways in which the normativities and ontologies that are the focus of commitment among those constituencies impact social and political processes.

To illustrate, the religious studies scholar Kocku von Stuckrad [54] noted that Roger Gottlieb's introduction to his book This Sacred Earth [55] contains "a cornucopia of ontologically laden expressions" ([54], p. 43), including "'our love of God's creation' or 'our simple joy in the divinity of the earth' ([55], p. 13). 'Making nature sacred' thus is a strategy that underlies not only products of literature ... but products of academic literature, too. From a critical scholarly point of view, these affirmations and admonitions are not an argument. They are data" ([54], p. 43). Likewise, normativities underlie some religious and scholarly argumentation, suggesting that religions and spiritualities that are environmentally positive are "better" than other religions. As von Stuckrad put it, "That is why we have to put these normativities on the table and regard them as data of scholarly research" ([54], p. 43). Climate disruption need not necessarily be an "action" issue. When it is framed as such, the ontologies and normativities which support such claims should be interrogated. But it may also foster the sort of open-ended questioning and rumination that many who fear the instrumentalization of the humanities actually want [56].

For instance, climate disruption should be acknowledged a fact of existence for the next generation (those who are currently my students). How will they plan for their futures in an increasingly unpredictable world? Certainly one of the tools they will need at their disposal is the capacity to reflect on their own individual and collective values, and to be able to articulate a vision of a desirable future, a skill that the humanities supposedly excel in cultivating. They might be able to compare such visions with the likely outcomes if other current hegemonic visions of the future should continue to predominate. Such exercises can expand the horizon of ethical reflection by wrestling with the limits of the human moral imagination against a backdrop of truly global-scale change [57]. In short, there is a distinction between advancing normative positions with the affectively powerful category of religion, a project in which many scholars are actively engaged [46-52,58], and the analysis and the empirical study of the academic and popular constituencies they target $[9,44,59]$. In other words, there is a difference between making religion about climate change, and thinking about the academic study of religion, the academy, and its usefulness (or lack of it) through the lens of climate change. To borrow an analytical frame first deployed by the scholar of religions Russell McCutcheon [37], some are caretakers of the fields in which they work and the categories that are central to them. Others are critics of them and attempt to analyze the ways in which they either challenge or reinforce the enactment of specific power-laden social arrangements. In reality, only the former are participating in the worrisome project that Strenski and others object to. If anything the latter group should help to clarify the values (both explicit and implicit) which drive ideological public debates. Admittedly, though, both Strenski and McCutcheon have in mind a somewhat binary perception of the problem, imagining that one can occupy only one or the other camp (academics vs. activists, critics vs. caretakers). There is a certain amount of privilege (intellectual, social, and ecological) behind such assumptions, as though we could view these oppositional approaches from a god's-eye perspective. In fact, I suspect that many, even most scholars (and this is true of those who work in any discipline) more likely have their own normative presuppositions, and particular interests which drive their research and scholarship. I argue that engaged scholarship can be good scholarship, and I aim here to provide some examples of how grounded, problem-based scholarship can cultivate more integrated communities, and provide rich data for humanities scholars who are interested in the nexus of values and spiritual sensibilities. 


\section{Can Engaged Scholarship be Good Scholarship?}

Alongside the always political posturing that bounds the field of religious studies, there are also some "social facts", as Durkheim would have it [60]. ${ }^{7}$ These can and should be integrated into explanatory (and not just descriptive) research. Today, many of those social facts have to do with climate disruption and sustainability. There are quantifiable ecological, social, and economic impacts of climate disruption, and sustainability movements and discourses which offer various solutions to these interwoven crises. Important questions bubble up: Is it possible to study cultures, as anthropologists do, without noting that there has been a dramatic erosion of indigenous cultures across the globe in the past few centuries? Or is it possible to study biological organisms and ecosystem services without noticing that there has been a dramatic drawdown in biological diversity in the past century? Is it possible to study religion in an age of climate disruption and not inquire whether and/or to what extent religious individuals, groups, and ideologies contribute to this global problem? No, these developments are predictable outcomes of what we might now call socio-ecological facts. Problem-based and engaged teaching and learning is one valuable strategy that is common across contexts which aim toward education for sustainability, and one of the ways in which we can imagine that education might actually foster more a sustainable civilization.

To elaborate, "activist anthropologists" emerged at least as early as the 1960s, advocating the rights of indigenous people to sovereignty and self-determination in an era when globalizing trends were obviously eradicating them at an alarming rate [61]. Few would argue that this was a faddish development, or that it distracted from some essentialized mode of pure research at the real heart of anthropology. Likewise restoration ecology, while practiced rather informally through a handful of projects since the early 20th century became in the mid-1980s a robust discipline with a scholarly society and affiliated journal $[62,63]$. This was spurred by "the growing recognition of the value of restoration as a conservation strategy, a technique for basic ecological research, a way of experiencing about landscapes and ecosystems" ([63], p. 1379). It had both normative value (as a conservation strategy), and scientific value (as a lens for "basic" research) ${ }^{8}$ Far from compromising this discipline, these developments provided new avenues for exploration, enlivening it and encouraging connections with others. Conservation biology emerged in similar fashion, with an academic society and affiliated journal arising in 1986, driven by concerns that humans might be forcing a mega-extinction across trophic levels. Importantly, some have even argued that some of its foundational characters, scientists such as Michael Soulè and Reed Noss, were motivated by some form of nature spirituality [64-66]. Again, this helped the science of biology develop in new directions, spurring new lines of inquiry, and opening new lines of communication with others, including scholars of religion. Currently many conservation biologists are on the frontlines of the fight against both biodiversity collapse and displacement of marginalized peoples, since the causes of both of these symptoms are often the same, namely agricultural or industrial usurpation of resources and land for profit generation. In these other disciplines there seems to be very little hand-wringing regarding whether or not they were appropriate developments in those fields.

David Orr once wrote that all education is environmental education. To the extent that education either ignores, downplays, or dismisses ecosystems and habitats, or suggests that such things should be examined by only scholars in this or that discipline, then this is itself a lesson in the ways in which we imagine and relate to the environment. Richard Carp, quoting the psychologist Mihaly

7 As Durkheim put it, social facts are "external to individual minds considered as such, in the same way as the distinctive characteristics of life are external to the mineral substances composing the living beings" ([61], p. 70). Durkheim's goal was to differentiate these from mere psychological facts. I would add that some social facts are also "ecological facts", since the biophysical limitations of the planetary system are obviously also recognized by both civil society, governments, and corporate entities across the globe.

8 While I quote Jordan approvingly here, I think that the distinction between "basic" and "normative" research should be jettisoned. 
Csikszentmihalyi, noted that material culture "'compete[s] with humans for scarce resources'; our survival depends on establishing a relationship with material culture that builds, rather than frays, resilience. The antidote to an 'addiction to objects' is 'a genuinely rich symbolic culture ... poetry, songs, crafts, prayers, and rituals.' If he is right," Carp continues, "the doorway to resilience opens in a revised practice of the academic backwaters of art, music, theatre, religion, and philosophy" ([1], p. 228). Bringing a concern for the ecosystems in which we participate is neither a fad, nor does it necessarily compromise the rigor of any discipline or scholarly approach. Quite simply, all scholarship is interested scholarship. To declare certain areas of inquiry or modes of study out of bounds for religious studies scholars is to participate in political contestations over the "authenticity" of our discipline. Russell McCutcheon discussed such contestations related to public understandings of Islam, but his point is germane to other public contests over authenticity: the task of the cultural critic is to pick up the faint waft of dung that remains after we try to "sanitize the unsightly and the unruly by means of binary distinctions portrayed as nature. For it is the faint odor of rhetorical bullshit that provides evidence that the world of cultural artifacts [in which we might place the study of religions] is infinitely more complex" than the representations of those who generate such oppositions would have us think ([67], p. 58). The odor becomes especially pungent when people who study religions attempt to bound their studies by declaring certain explorations off limits, or beyond the edge of some always political disciplinary map. The jargon of authenticity is one of the sharpest weapons that can be forged with the category "religion", and it is wise to cast our critical gaze toward how such sharp edges are deployed in the public sphere. To let those edges cut humanities and social science scholars out of particularly relevant cultural questions is itself one of the primary drivers of unsustainable educational outcomes.

When it comes to knowledge practices, Carp insisted, "There is nowhere 'outside' from which to know. There are not two zones, one of ecology (nature) and one of culture (human), so that the question is of the impact of the culture on the ecology. Rather, cultural landscapes and their components participate fully in the developmental system of which they are a part" ([1], p. 224). The academy, therefore, is not only complicit in climate disruption and the fraying of resilience across multiple scales, it is one of the primary drivers of these trends: "The ecological crisis is not an 'accident' of cultural development; it is a necessary correlate of our knowledge practices" ([1], p. 225). The solution is to re-evaluate the ways in which scholars and their bodies create knowledge practices, to recognize that good knowledge practices should be less concerned with "accuracy" and centrally concerned instead with practices that enable communities to live well ([1], p. 225; [68], p. 73). An example from the well-known anthropologist Darrell Posey will be illustrative. He recalled that once while staying with his host family in the Xingu River Basin in the Brazilian Amazon he disposed of a significant quantity of tapir meat after finding that it was infested with maggots. He also recalled the apparent delight of passing neighbors when they observed him, and the surprise and anger of his hosts when they returned. Posey was unaware that the maggots' saliva contained an enzyme which cured the meat, preserving it for future consumption ([20], p. 232; [69], p. 54). This is an example of traditional ecological knowledge, wisdom tied to particular places and contexts, which is not always easily or directly translated into western or other cultural contexts. But it's valuable knowledge, nonetheless. Sometimes it's good to let the maggots eat. And sometimes it's good to encourage new modes of inquiry in an educational system that has largely lost its way.

\section{Strategies for Integrative Learning across Disciplines}

Indeed, attending to what he calls "indigenous education" is one of the strategies Carp suggested for creating more relevant educational systems. Why are things like traditional ecological knowledge important for education for sustainability? Because they weave together empirical knowledge, normative propositions (including rumination about other-than-human entities with whom we co-habitate), and practical action aimed at solving specific societal needs. It is a more embodied form of knowledge production and deployment. "Embodied scholarship", Carp noted, is another 
strategy for promoting change, and it is of course related to modifying the ways in which scholars imagine their vocation, and the strategies by which they pursue their learning outcomes. The science writer Nicholas Wade noted that "a person should really be considered a superorganism ... consisting of his or her own cells and those of all the commensal bacterial. The bacterial cells also outnumber human cells by 10 to 1 , meaning that if cells could vote, people would be a minority in their own body" ([70]; quoted in [71], p. 85). Viewing our scholarly bodies as ecosystems, along with imagining how we tack toward indigenous education requires rejection of the traditional siloed approach to education by refusing to recognize a distinct divide between knowledge and action, and by prioritizing wisdom and values in both lifeways and in policy deliberation [3]. Similarly, professor of Chinese Studies James Miller has elucidated a plan for what he calls education from the outside-in, which "means that students' learning will be oriented towards the problems of the real world, not the problems as conceived and articulated within the historic university disciplines" [72]. Like Carp's examples of embodied and indigenous education, this includes thinking about learning outcomes by putting values, wisdom, and skills first, and by increasing educational breadth, not specialization. As Miller put it, "outside-in education means learning how to know what facts are important in which contexts (valuing), how to deploy knowledge to achieve practical results (skills), and how to decide what goals are truly worthwhile (wisdom)." The ethicists Anthony Weston and Jim Cheney [73] influentially argued that Western ethical reflection typically depends on an epistemology-grounded ethics-the assumption that the world is readily knowable, and that ethical action is a response to knowledge about the world. In this approach, ethics is an incrementalist and extensionist business: the task is to sort the world ethically, to articulate the nature of things in ethical terms. In contrast, an ethics-based epistemology, the sort employed by indigenous and traditional cultures, considers ethical reflection an exercise in relational exploration, an attempt to open up possibilities and enrich the world by engaging both with what is known, and what is unknown. In this model, ethics is not a response to an already known world, but draws on wisdom and encounter, and aims at perceiving a pluralistic, dissonant, and discontinuous world rather than attempting to incrementally extend epistemology-based ethics to other entities.

To move from these more theoretical examples toward the practical, it will be helpful to review some data which further illustrate that sustainability is not simply a faddish social movement. At this writing 772 institutions of higher learning are registered as using the Sustainability Tracking and Rating System (STARS), a program designed and deployed by the Association for the Advancement of Sustainability in Higher Education (AASHE) to measure sustainability outcomes. Well over 600 college and university presidents have signed on to the President's Climate Commitment, a statement of purpose which obligates these institutions to pursue a carbon action plan. These are high-level commitments which simply illustrate the breadth and depth of concern about these issues. But what do they mean in the context of creating a more sustainable academy? Some concrete examples will be illustrative.

Two of my colleagues in the Department for the Study of Religions found their research growing enmeshed with some of their other interests. Ulrike Wiethaus was working with youth from the Eastern Band of Cherokee, in North Carolina, helping them train to take the MCAT exams, and also on a literacy program with inmates at a maximum security prison. Steve Boyd was working with the San Carlos Apache to halt construction of large telescopes on Mount Graham, a sacred site, and increasingly found himself entangled in a murder investigation in Winston-Salem. They began to drawtheir lessons into the classroom, using them of examples of how, and under what circumstances, religious individuals and groups could be impactful. Beginning with pilot internships which reflected both community needs and the interests of individual students, they created a Religion and Public Engagement Concentration, open to students from any major. The concentration was approved by the full faculty in 2011, and graduated its first true concentrators in 2012. To date, forty-seven students have completed the requirements. It was from its inception not merely another internship program, but coupled engaged learning with a community partner with academic work relevant to student 
interests. Students meet with the faculty director once a week, along with composing weekly journals, several book reviews of relevant works, and an integrative final paper. The concentration is both academically rigorous, and fundamentally about problem-based, engaged knowledge [74].

Boyd helped to develop an interfaith group who lobbied a district attorney to end his defense of a wrongful conviction, after which the defendant was exonerated by DNA evidence after being wrongfully imprisoned for nineteen years [75]. He continues to work on similar projects in the Winston-Salem area, including the case of Kalvin Michael Smith, imprisoned for eighteen years (so far) in an improperly prosecuted and likely racially-charged case [76]. Wiethaus's work with the Cherokee aims to preserve traditional knowledge (which is significantly related to spirituality) with Western medical knowledge to increase their success on standardized tests. Like broader understandings of sustainability, education for sustainability fundamentally depends on social equity and justice, and trustworthy monitory and enforcement agencies. These are exercises, then, in building community capital and resilience which leverage spiritual and religious knowledge.

These are but a few examples specific to our campus, but ones that are easily generalizable to others. Any university or college of any size can facilitate engaged and service learning opportunities for students. At least at my own institution, the results in terms of impactful student learning speak for themselves. Opportunities for engagement have shaped career and further educational choices, and actually helped to contribute to cultivating a more resilient and transparent local community.

\section{Conclusions and a Look Ahead}

Other approaches might be more site-specific, drawing on local resources. For instance, in collaboration with Wiethaus, we have also begun to cultivate the "Cherokee Meditation Garden" in collaboration with campus landscape services, the indigenous students' organization, and in consultation with the Eastern Band of Cherokee. The "garden" is really the land around a retention pond built to control storm water runoff. But it has become a quiet corner of the campus where, with no formal funding, we have been able to begin to replace invasive plant regimes with traditional medicinal varieties. Wiethaus uses it each year for her MCAT training class with Cherokee youth. It is a work in progress, but it is also a classroom tool for discussing restoration ecology (one of the other normatively-grounded disciplines noted above), and an exercise in place-making. Wake Forest's motto is Pro Humanitate, for the human good, and at least ideally our curriculum is designed not just to facilitate student learning, but educational outcomes that contribute in some meaningful way to the communities in which people live, work, and play. To that end, our university has sponsored the creation of a new Pro Humanitate Institute, designed to facilitate such public engagement and exposure to non-profit organizations that help build sustainable communities. These examples are, of course, not generalizable to any campus, but the values that drive them may be.

Strategies for bringing sustainability education into the classroom vary, from the "infusion model", in which integrative education permeates curricular offerings, to the "unique discipline model", in which sustainability becomes its own holistic area of study. Examples of both abound [77], but common to all of examples of best practices is dispensing with tired old assumptions about certain types of questions and research being the proprietary terrain of one or another discipline or set of disciplines.

The toolkits of religious studies scholars vary widely. What I am suggesting is that there appears to be an increasing emphasis on training related to empirical methods, whether the push toward the study of lived religion, or the increasing importance of field work methodology in advanced graduate training, or in the emerging importance of explanatory (rather than merely descriptive) research pioneered by those in the fields of cognitive science of religion [78-83], evolutionary psychology [84-86]; cognitive ethology [87,88], and even primatology [89-91]. Religious studies scholars engaged in these modes of explanatory research take as some of their primary data the ways in which humans are shaped by biological inheritance, ecological constraints, and psychological predispositions. Among the factors which shape all three of these today are the complex and multi-scalar effects of climate disruption, the 
increasing urbanization of human social life, demographic shifts (both voluntary and involuntary), and attempts to rethink social life within these dynamic constraints. Climate disruption and sustainability are important global trends and highly influential in the global political economy of the sacred. One of the tasks of humanities scholars is to discern the consonances and divergences between different deployments of these terms in the public sphere. They are well suited for this since sustainability discourse has at its roots religious individuals, metaphors, and concepts, and climate change traffics in highly affective narratives of ecosystem decline if not apocalypse. Moreover, teaching and research can bend toward a more problem-focused, grounded theoretical stance, and methodologies that view religious behaviors and ideologies, and the ontological and normative assumptions that accompany them, as data for analysis, not starting points for reflection. It is time that scholars of religions and our students shouldered our religious baggage, owning it for what it is, and carrying it toward the future. Understanding which way to go, which maps to follow, can only be the result of processes of rethinking our modes of knowledge production, and the knowledge practices which legitimize them. Our models of what happens if we sally forth with existing knowledge practices are unequivocal: there are unpredictable and catastrophic consequences which will undoubtedly yield great suffering for humans and for many of the species with which we have co-evolved. It is not merely appropriate but necessary that we pursue a new mode of research and of education if our own species and the academy (not to mention the contemporary geo-political landscape) are to persist.

Conflicts of Interest: The author declares no conflict of interest.

\section{References}

1. Carp, Richard. “Toward a Resilient Academy.” In Higher Education for Sustainability: Cases, Challenges, and Opportunities Across the Curriculum. New York: Routledge, 2013, pp. 233-37.

2. Orr, David. Ecological Literacy: Education and the Transition to a Postmodern World. Albany: SUNY Press, 1991.

3. Van Lopik, William. Keys to Breaking Disciplinary Barriers that Limit Sustainable Development Courses. New York: Routledge, 2012, pp. 79-92.

4. Chidester, David. Authentic Fakes: Religion and Popular Culture in America. Berkeley: University of California Press, 2005.

5. Strenski, Ivan. "Can Religion Professors Save the Planet?" Religion Dispatches, 9 December 2014. Available online: http:/ / religiondispatches.org/can-religion-professors-save-the-planet/ (accessed on 5 March 2016).

6. Veldman, Robin Globus. "An Inconvenient Faith? Conservative Christianity, Climate Change and the End of the World." Ph.D. Dissertation, University of Florida, Gainesville, FL, USA, 2014.

7. Smith, Jonathan Z. "Religion, Religions, Religious." In Critical Terms in Religious Studies. Edited by Mark Taylor. Chicago: University of Chicago Press, 1998, pp. 269-84.

8. Smith, Jonathan Z. Imagining Religion: From Babylon to Jonestown. Chicago: University of Chicago Press, 1982.

9. Johnston, Lucas F. Religion and Sustainability: Social Movements and the Politics of the Environment. London: Equinox, 2013.

10. Worster, Donald. Nature's Economy: A History of Ecological Ideas. Cambridge and New York: Cambridge University Press, 1994.

11. Berkes, Fikret, Carl Folke, and Johan Colding. Linking Social and Ecological Systems: Management Practices and Social Mechanisms for Building Resilience. Cambridge and New York: Cambridge University Press, 1998.

12. Naylor, D. Keith. "Pinchot, Gifford." In Encyclopedia of Religion and Nature. London: Continuum, 2005, vol. 2.

13. Gifford Pinchot. Breaking New Ground. New York: Harcourt, Brace \& Company, 1910.

14. Rist, Gilbert, and Patrick Camiller. The History of Development: From Western Origins to Global Faith. London and New York: Zed, 1997.

15. Tuveson, Ernest. Redeemer Nation: The Idea of America's Millenial Role. Chicago: University of Chicago Press, 1980.

16. Johnston, Dedee DeLongprè, and Lucas Johnston. "Introduction: What's Required to Take EfS to the Next Level?" In Higher Education for Sustainability: Cases, Challenges, and Opportunities Across the Curriculum. New York: Routledge, 2013, pp. 1-8. 
17. Trägårdh, Lars, Nina Witoszek, and Bron Raymond Taylor. Civil Society in the Age of Monitory Democracy. New York: Berghahn, 2013.

18. Patterson, Bobbi, and Puckett Robert. "Resilience, Lived Scholarship, and Sustainable Life." Journal of the American Academy of Religion 83 (2015): 407-21. [CrossRef]

19. Taylor, Bron. "Critical Perspectives on the Religions of the World and Ecology." In Encyclopedia of Religion and Nature. Edited by Bron Taylor. London: Continuum, 2005, vol. 2, pp. 1375-76.

20. Johnston, Lucas F., and Todd LeVasseur. "Indigenous and Traditional Resource Management." In Berkshire Encyclopedia of Sustainability: Natural Resources and Sustainability. Great Barrington: Berkshire Press, 2011, pp. 232-39.

21. Glacken, Clarence J. Traces on the Rhodian Shore: Nature and Culture in Western Thought from Ancient Times to the End of the Eighteenth Century. Berkeley: University of California Press, 1967.

22. Burkert, Walter. Creation of the Sacred: Tracks of Biology in Early Religions. Cambridge: Harvard University Press, 1996.

23. Rappaport, Roy Abraham. "Ritual in the Ecology of a New Guinea People: An Anthropological Study of the Tsembaga Maring." Ph.D. Dissertation, Columbia University, 1966.

24. Rappaport, Roy A. Ritual and Religion in the Making of Humanity. Cambridge and New York: Cambridge University Press, 1999.

25. Lansing, John Stephen. Priests and Programmers: Technologies of Power in the Engineered Landscape of Bali. Princeton: Princeton University Press, 1991.

26. Müller, F. Max. Natural Religion: The Gifford Lectures Delivered before the University of Glasgow in 1888. London and New York: Longmans, Green, and Co., 1889.

27. Schultes, Richard Evans, and Siri Von Reis. Ethnobotany: Evolution of a Discipline. Portland: Dioscorides Press, 1995.

28. Shepard, Paul, and Florence R. Shepard. Coming Home to the Pleistocene. Washington: Island Press, 1998.

29. Wilson, Edward O. Biophilia. Cambridge: Harvard University Press, 1984.

30. Berry, Evan. “'Saving the Planet' Sounds Strangely Religious: A Response to Ivan Strenski." Religion Dispatches, 2014. Available online: http://religiondispatches.org/saving-the-planet-sounds-strangelyreligious-a-response-to-ivan-strenski/ (accessed 19 September 2016).

31. Cook, John, Dana Nuccitelli, Sarah A. Green, Mark Richardson, Bärbel Winkler, Rob Painting, Robert Way, Peter Jacobs, and Andrew Skuce. "Quantifying the Consensus on Anthropogenic Global Warming in the Scientific Literature." Environmental Research Letters 8 (2013): article 024024. [CrossRef]

32. For more details see Public Religion Research Institute. Available online: http://www.prri.org/research/ believers-sympathizers-skeptics-americans-conflicted-climate-change-environmental-policy-science/ (accessed on 7 July 2016).

33. The Guardian. Available online: https://www.theguardian.com/environment/2012/sep/17/arcticcollapse-sea-ice (accessed on 13 March 2016).

34. Prothero, Stephen. Religious Literacy: What Every American Needs to Know, and Doesn't. New York: HarperOne, 2008.

35. Hughes, Aaron. "Revolutionary Love: Scholars Respond to the AAR's 2016 Conference Theme: Aaron Hughes." Bulletin for the Study of Religion, 10 February 2016. Available online: http:/ / bulletin.equinoxpub.com/2016/ 02/revolutionary-love-scholars-respond-to-the-aars-2016-conference-theme-aaron-hughes/ (accessed on 22 September 2016).

36. McCutcheon, Russell. Manufacturing Religion: The Discourse on Sui Generis Religion and the Politics of Nostalgia. New York: Oxford University Press, 1997.

37. McCutcheon, Russell T. Critics Not Caretakers: Redescribing the Public Study of Religion. Albany: State University of New York Press, 2001.

38. Masuzawa, Tomoko. The Invention of World Religions, or, How European Universalism Was Preserved in the Language of Pluralism. Chicago: University of Chicago Press, 2005.

39. Dubuisson, Daniel. The Western Construction of Religion: Myths, Knowledge, and Ideology. Baltimore: Johns Hopkins University Press, 2003.

40. Orsi, Robert. "Everyday Miracles: The Study of Lived Religion." In Lived Religion in America: Toward a History of Practice. Princeton: Princeton University Press, 1997, pp. 3-21. 
41. Goldenberg, Naomi. "Revolutionary Love: Scholars Respond to the AAR's 2016 Conference Theme: Naomi Goldenberg." Bulletin for the Study of Religion, 15 February 2016.

42. Latour, Bruno. Politics of Nature: How to Bring the Sciences into Democracy. Cambridge: Harvard University Press, 2004.

43. Bauman, Whitney, Richard Bohannon, and Kevin J. O'Brien. Inherited Land: The Changing Grounds of Religion and Ecology. Eugene: Pickwick Publications, 2011.

44. Taylor, Bron Raymond. Dark Green Religion: Nature Spirituality and the Planetary Future. Berkeley: University of California Press, 2010.

45. Taylor, Bron. "Exploring Religion, Nature and Culture-Introducing the Journal for the Study of Religion, Nature and Culture." Journal for the Study of Religion, Nature E Culture 1 (2007): 5-24. [CrossRef]

46. Tucker, Mary Evelyn, and Duncan Ryuken Williams. Buddhism and Ecology: The Interconnection of Dharma and Deeds. Cambridge: Harvard University Press, 1997.

47. Tucker, Mary Evelyn, and John H. Berthrong. Confucianism and Ecology: The Interrelation of Heaven, Earth, and Humans. Cambridge: Harvard University Press, 1998.

48. Chapple, Christopher Key. Hinduism and Ecology: The Intersection of Earth, Sky, and Water. Cambridge: Harvard University Press, 2000.

49. Chapple, Christopher Key. Jainism and Ecology: Nonviolence in the Web of Life. Cambridge: Harvard University Press, 2002.

50. Hessel, Dieter T., and Rosemary Radford Ruether. Christianity and Ecology: Seeking the Well-Being of Earth and Humans. Cambridge: Harvard University Press, 2000.

51. Grim, John. Indigenous Traditions and Ecology: The Interbeing of Cosmology and Community. Cambridge: Harvard University Press, 2001.

52. Tirosh-Samuelson, Hava. Judaism and Ecology: Created World and Revealed Word. Cambridge: Harvard University Press, 2002.

53. Johnston, Lucas F., and Taylor Bron. "Religion and Environmental Politics into the Twenty-First Century and Beyond." In The Wiley Blackwell Companion to Politics and Religion in America. West Sussex: Wiley Blackwell, 2016.

54. Von Stuckrad, Kocku. "Finding Data: Some Reflections on Ontologies and Normativities." Journal for the Study of Religion, Nature E Culture 1 (2007): 39-46. [CrossRef]

55. Gottlieb, Roger S. This Sacred Earth: Religion, Nature, Environment. New York: Routledge, 1996.

56. Journal of the American Academy of Religion 83 (2015) which includes a special roundtable on "Climate Destabilization and the Study of Religion".

57. Morton, Timothy. Hyperobjects: Philosophy and Ecology after the End of the World. Minneapolis: University of Minnesota Press, 2013.

58. Grim, John, and Mary Evelyn Tucker. Ecology and Religion. Washington: Island Press, 2014.

59. Sponsel, Leslie E. Spiritual Ecology: A Quiet Revolution. Santa Barbara: Praeger, 2012.

60. Durkheim, Émile, and Anthony Giddens. Selected Writings. Cambridge: Cambridge University Press, 1972.

61. Wright, Robin. "Anthropological Presuppositions of Indigenous Advocacy." Annual Review of Anthropology 17 (1988): 365-90. [CrossRef]

62. Jordan, William R. The Sunflower Forest: Ecological Restoration and the New Communion with Nature. Berkeley: University of California Press, 2003.

63. Jordan, William, III. "Restoration Ecology and Ritual." In Encyclopedia of Religion and Nature. London: Continuum, 2005, vol. 2, pp. 1379-81.

64. Johnston, Lucas F. "From Biophilia to Cosmophilia: The Role of Biological and Physical Sciences in Promoting Sustainability Healing." Journal for the Study of Religion, Nature and Culture 4 (2010): 7-23. [CrossRef]

65. Jones, Lisa. "The Buckshot Bodhisattva." Tricycle: The Buddhist Review 13 (2003): 89-91, 122-25.

66. Takacs, David. The Idea of Biodiversity: Philosophies of Paradise. Baltimore: Johns Hopkins University Press, 1996.

67. McCutcheon, Russell. Religion and the Domestication of Dissent, or, How to Live in a Less than Perfect Nation. London and Oakville: Equinox Pub., 2005.

68. Carp, Richard. "Integrative Praxes: Learning from Multiple Knowledge Formations." Issues in Integrative Studies 19 (2001): 71-121.

69. Posey, Darrell, and Kristina Plenderleith. Indigenous Knowledge and Ethics. New York: Routledge, 2004. 
70. Wade, Nicholas. "6 Tribes of Bacteria, the Good Kind, Found to Be at Home in Inner Elbow." The New York Times, 23 May 2008.

71. Harvey, Graham. Food, Sex and Strangers: Understanding Religion as Everyday Life. New York: Routledge, 2013.

72. Miller, James. “Turning University Education Outside-in.” James Miller 苗建時, 31 December 2014. Available online: http:/ / www.jamesmiller.ca/teaching/outside-in-education/ (accessed on 22 September 2016).

73. Weston, Anthony, and Jim Cheney. "Environmental Ethics as Environmental Etiquette: Toward an Ethics-Based Epistemology." Environmental Ethics 21 (1999): 115-34.

74. Religion and Public Engagement. 2016. Available online: http://college.wfu.edu/rpe/ (accessed on 6 July 2016).

75. Innocence Project. 2016. Available online: http://www.innocenceproject.org/cases/darryl-hunt/ (accessed on 6 July 2016).

76. Free Kalvin Now. 2016. Available online: http:/ / freekalvinnow.org/ (accessed on 6 July 2016).

77. Johnston, Lucas F. Higher Education for Sustainability: Cases, Challenges, and Opportunities across the Curriculum. New York: Routledge, 2013.

78. Tremlin, Todd. Minds and Gods: The Cognitive Foundations of Religion. New York: Oxford University Press, 2006.

79. Taves, Ann. Religious Experience Reconsidered: A Building Block Approach to the Study of Religion and Other Special Things. Princeton: Princeton University Press, 2009.

80. Atran, Scott. In Gods We Trust: The Evolutionary Landscape of Religion. Oxford and New York: Oxford University Press, 2002.

81. Pyysiäinen, Ilkka. How Religion Works: Towards a New Cognitive Science of Religion. Leiden and Boston: Brill, 2001.

82. McCauley, Robert N., and E. Thomas Lawson. Bringing Ritual to Mind Psychological Foundations of Cultural Forms. Cambridge and New York: Cambridge University Press, 2002.

83. Whitehouse, Harvey. Modes of Religiosity: A Cognitive Theory of Religious Transmission. Walnut Creek: AltaMira Press, 2004.

84. Boyer, Pascal. Religion Explained: The Evolutionary Origins of Religious Thought. New York: Basic Books, 2001.

85. Kirkpatrick, Lee A. Attachment, Evolution, and the Psychology of Religion. New York: Guilford Press, 2005.

86. Wilson, David Sloan. Darwin's Cathedral: Evolution, Religion, and the Nature of Society. Chicago: University of Chicago Press, 2002.

87. Bekoff, Marc. Animal Passions and Beastly Virtues: Reflections on Redecorating Nature. Philadelphia: Temple University Press, 2006.

88. Bekoff, Marc. "Cognitive Ethology, Social Morality, and Ethics." In Encyclopedia of Religion and Nature. Edited by Bron Taylor. London: Continuum, 2005, pp. 397-99.

89. King, Barbara J. Evolving God: A Provocative View of the Origins of Religion. New York: Doubleday, 2007.

90. De Waal, Frans. B. M. Good Natured: The Origins of Right and Wrong in Humans and Other Animals. Cambridge: Harvard University Press, 1996.

91. De Waal, Frans. B. M. The Age of Empathy: Nature's Lessons for a Kinder Society. New York: Harmony Books, 2009.

(C) 2016 by the author; licensee MDPI, Basel, Switzerland. This article is an open access article distributed under the terms and conditions of the Creative Commons Attribution (CC-BY) license (http://creativecommons.org/licenses/by/4.0/). 